\title{
Jabr Omar, professor de Economia. Uma trajetória entre o Brasil, a Palestina e o Canadá.
}

\section{Jabr Omar, professor of economics. A trajectory between Brazil, Palestine and Canada.}

Entrevistadores: Fábio Vergara Cerqueira e Guilherme Stefan Submetido em 16 e aprovado em 23 de agosto de 2018.

O Canadá é "second to none". Para mim, alguém pode dizer que tem um país igual, mas melhor você não pode encontrar. Para os jovens, um país de oportunidades; para os profissionais, um país de crescimento e desenvolvimento; para os velhos, um país de descanso, e garantia de dignidade humana. Para a criança, o Canadá oferece todos os privilégios. Jabr H. D. H. Omar

\section{Apresentação por Fábio Vergara Cerqueira}

Professor Omar, como é tratado na UFPel, ou ainda Maisar, como é carinhosamente conhecido e respeitado pela numerosa comunidade árabe da fronteira meridional do Brasil, o professor Dr. Jabr Hussein Deeb Haj Omar destaca-se, ao mesmo tempo, pela sua carreira acadêmica e pela liderança palestina na América Latina. Nascido na Palestina, onde fez seus estudos iniciais, sua família está radicada há muitos anos no Chuí brasileiro. Realizou seus estudos de pós-graduação no Canadá, onde atualmente seus filhos fazem a formação universitária, em busca da qualidade da educação canadense. Homem do mundo, possui cidadania palestina, brasileira e canadense. Exemplo de sua representatividade comunitária, foi Secretário-Geral da Confederação Palestina da América Latina e do Caribe (COPLAC), entre 1987 e 1993, e Secretário-Geral adjunto, de 1993 até 2017, cargo que lhe colocou em contato próximo com líderes internacionais da estatura de Yasser Arafat. 


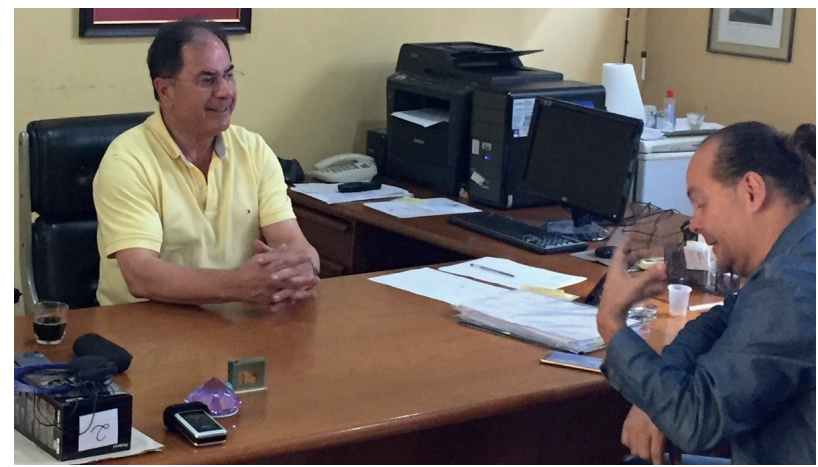

Prof. Omar recebe Fábio Vergara Cerqueira, no gabinete da Direção do Centro de Integração do Mercosul (UFPel), para entrevista.

Iniciou sua vida acadêmica na Jordânia, formando-se bacharel em Ciências Econômicas e Estatísticas pela Jordain University, em Amã, em 1972. Seus estudos de pós-graduação foram realizados na McGill University, em Montreal, obtendo título de mestre em Ciências Econômicas em 1980 e de doutor em Economia em 1985.Iniciou a carreira do ensino superior em 1991, como professor da Universidade Católica de Pelotas, e, logo em seguida, em 1992, como professor de Economia na Universidade Federal de Rio Grande (FURG), transferindo-se em 1998 para a UFPel. Vinculou-se ao Instituto de Ciências Humanas (ICH), responsável pela disciplina de Economia ministrada aos cursos de Geografia e de Direito. A partir de 2000, atuou como professor do recém-criado curso de Economia da UFPel, sediado no ICH. Foi como professor de Macroeconomia, Doutrinas Econômicas e Economia Internacional que contribuiu para a formação de toda uma geração de economistas da UFPel, fazendo contraponto à corrente neoliberal predominante na área.

Entre 2002 e 2010, atuou na gestão acadêmica, exercendo o cargo de ViceDiretor do ICH. Neste período, enquanto eu exercia a função de Diretor do ICH, tive a oportunidade de conviver de perto com o professor Omar, e assim de conhecer seu compromisso com a instituição da universidade pública e gratuita, sua visão sobre o papel da universidade para o desenvolvimento do país e seus ideais keynesianas sobre o papel do Estado para o desenvolvimento da economia e sociedade. Participei, junto ao professor 
Omar, da idealização do curso de Relações Internacionais, do qual o professor se tornou o primeiro coordenador, função que exerceu até assumir em 2011 o cargo de Diretor do Centro de Integração do Mercosul (CIM/UFPel), idealizado por ele juntamente ao então Reitor, professor Antonio Cesar Gonçalves Borges. Omar e Maisar assim se encontraram, pois sua trajetória como liderança palestina combinada à sua docência em Economia está na base de suas preocupações acadêmicas relativas à área das Relações Internacionais.

Atualmente segue, em seu segundo mandato, no exercício da direção do Centro de Integração do Mercosul, vinculado como docente ao curso de Relações Internacionais. $\mathrm{Na}$ área de Economia, destaca-se em Economia Monetária e Internacional, atuando principalmente nos seguintes temas: política monetária e fiscal, taxa de juros, teoria da integração econômica e desigualdade econômica. Entre suas pesquisas, podemos destacar sua contribuição aos estudos sobre taxa de juros (OMAR, 2008), sobre a perspectiva árabe-brasileira nos processos de globalização e regionalização (OMAR, 2001a) e sobre o papel do governo na economia (OMAR, 2001b).

Na tarde do dia 23 de maio, o professor Omar recebeu, no Gabinete da Direção do CIM/UFPel, os entrevistadores, professor Fábio Vergara Cerqueira, editor-adjunto da Interfaces, e o acadêmico do Curso de Direito da UFPel, Guilherme Stefan, para realização da entrevista. Ao fundo, uma fotografia emblemática, tirada em 1989: o jovem Omar, entre Yasser Arafat, "líder eterno" do povo palestino, e Sam Ngoma, primeiro presidente da Namíbia. Um retrato que recorda seu engajamento internacional em prol da causa palestina e indica seu ponto de vista no tema das relações internacionais. 


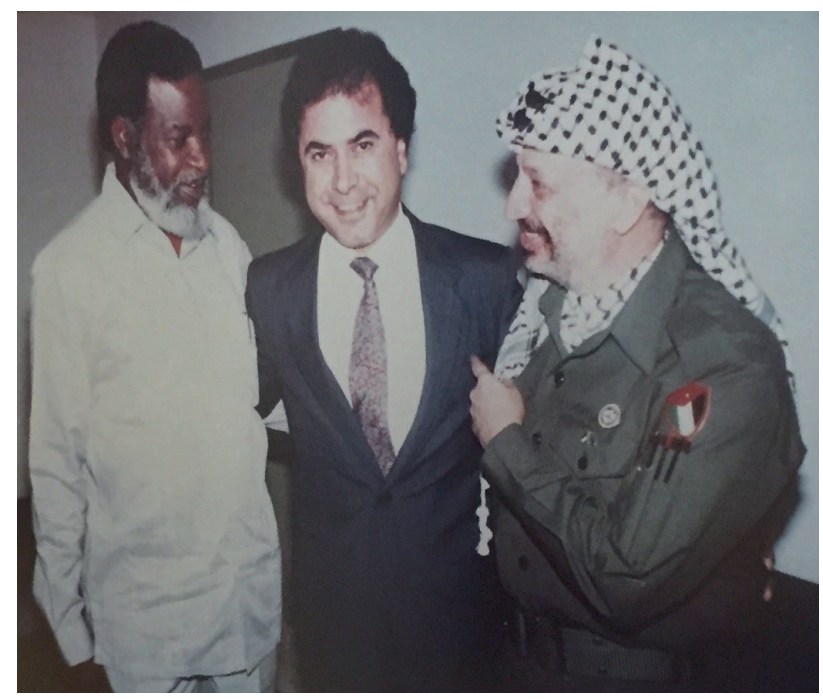

Prof. Jabr Omar, Yasser Arafat e Sam Ngoma, primeiro presidente da Namíbia (1989)

Apesar do ambiente institucional, mais formal, vários assuntos fluíram de maneira bastante espontânea, ao longo de quase duas horas de animada conversa. O entrevistado trouxe um depoimento muito rico sobre suas experiências e visões, nesta sua perspectiva de um enraizamento triangular, ao mesmo tempo brasileiro, palestino e canadense. Falouse de política imigratória, de multiculturalismo, de educação universitária, de análise de conjuntura econômica e política internacional, de diferenças e semelhanças entre Brasil e Canadá.

Entrevistadores: Prof. Dr. Fábio Vergara Cerqueira (F.V.C.), Guilherme Stefan (G.S.). Degravação: Guilherme Stefan

\section{Do começo, na Palestina, e a família, no Brasil}

(G.S.) O senhor nasceu onde?

(J.O.) Eu nasci em uma pequena localidade, no distrito de Ramallah, atual capital 
administrativa da Autoridade Nacional Palestina, que fica a aproximadamente $25 \mathrm{~km}$ ao norte de Bayt Lahm (Belém), a cidade onde nasceu Jesus Cristo. Então, eu vou a Belém e volto, de forma tranquila, naquele território que é denominado como Palestina. $\mathrm{Na}$ Bíblia, Jesus não nasceu em Israel, apesar de ser referido por certas pessoas como "aquele judeu”, mas na Palestina, e falava aramaico e não hebraico. Independente da religião, Jesus Cristo é palestino, porque se eu nasço no Brasil, e aqui nasce meu filho, meu filho é brasileiro, independente de ele ser muçulmano, cristão ou ateu. Independente da religião, ele é brasileiro. Nasci lá, de fato, fui criado lá. Acabei lá a High School, o segundo grau, nos anos de $1968,1969 \ldots$

(F.V.C.) Depois...

(J.O.) Depois fui para a Jordânia. Fiz lá a minha graduação, na Universidade de Amã. Observe, sou palestino de origem, nasci lá, fui à escola lá. Cursei a graduação lá. A pós-graduação eu fiz no Canadá. No entanto, eu trabalho no Brasil. Então, note, eu nasci em um continente, estudei em outro e trabalho em um terceiro continente.

\section{(G.S.) E por que o senhor veio para o Brasil?}

(J.O.) Por que eu vim para o Brasil? Vou dizer uma coisa na qual eu sempre penso: o destino do ser humano muitas vezes é feito por acidentes e não por planejamento. De fato, minha família morava aqui no Brasil.

\section{(G.S.) Vieram antes para cá?}

(J.O.) Sim, meu pai e minha mãe chegaram antes. Meu pai chegou no começo dos anos 1950; minha mãe, no final daquela década. Todos meus irmãos e irmãs são brasileiros natos. Eu sou o único que nasceu lá.

\section{(G.S.) Então o senhor é o mais velho?}

(J.O.) Eu sou o mais velho de uma família de sete filhos, quatro meninas e três meninos. Meu pai, como imigrante palestino, era, é claro, do comércio. Mas deu ensino para nós todos onde ele investiu todo o trabalho dele junto com minha mãe em nossa educação. 
(F.V.C.) Os sete estão no Brasil?

(J.O.) Os dois irmãos, que são médicos, e uma irmã, economista, estão aqui. As três irmãs estão trabalhando, todas, na Califórnia: duas são $\mathrm{PhD}$ em Psicologia e outra começou como jornalista, mas depois fez curso de estética e trabalha na área. Já eu tenho PhD em Economia no Canadá, e estou trabalhando aqui. Tudo o que meus pais tiveram, investiram em nossa educação.

\section{Os estudos universitários, da Jordânia ao Canadá}

(F.V.C.) Omar, tu fizeste teus estudos universitários no Canadá. Poderias nos falar como foi esta experiência?

(J.O.) Muito bem, doutor Fábio. Sabe, eu sempre falo que o destino muitas vezes é feito por acidentes, não por planejamento. Quando fiz uma visita a meus pais, aqui no Brasil, encontrei um amigo meu, com quem estudei e me formei, lá na Universidade da Jordânia (Jordan University). Ele me contou que estava morando no Canadá e que pretendia apresentar uma candidatura para pós-graduação em universidades de lá. Então me disse: “O que você acha de vir para o Canadá?”. Olha, o Canadá sempre esteve fora do meu pensamento. Eu pensava, enfim, que as melhores universidades estavam nos Estados Unidos. Mas depois, quando ele ingressou na McGill University, ele me mandou um material. Olhei tudo, e falei: "Então está certo". Para minha sorte, fui aceito na universidade. Naquela época, eu tinha apenas um diploma de Bacharelado em Economia e Estatística, obtido em uma universidade estrangeira.

(F.V.C.) A tua graduação foi onde?

(J.O.) Na Universidade da Jordânia, em Amã. Em McGill fui aceito no mestrado em Economia. Mas colocaram algumas condições. Primeiro, como não tínhamos estudos canadenses, exigiram um ano de qualificação (qualifying year). Você tem de provar que está qualificado para continuar no curso de pós-graduação. Neste ano de qualificação, você cursa quatro disciplinas chave no curso de graduação da universidade. Para poder prosseguir no mestrado, você tem de passar nessas quatro disciplinas com média mínima 
de sete. E tudo deu bem comigo. Assim entrei no programa de mestrado em Economia. Após concluir o mestrado, passei para o doutorado, também na McGill.

(G.S.) Fale-nos sobre a sua experiência como estudante de pós-graduação na McGill?

(J.O.) Eu sou grato por meus pais que me deram a oportunidade de estudar em uma das melhores universidades do Canadá e do mundo. Tenho o privilégio de ter sido estudante de excelentes professores, de dispor de excelente biblioteca, excelente infraestrutura e excelente ambiente estudantil e social em Montreal. Enfim, foi uma experiência muito enriquecedora. Foi uma oportunidade muito rica para conhecer alunos de outros países. Conheci professores de primeira categoria, com renome internacional, com quem pude cursar diferentes disciplinas e seminários. E Montreal para o Canadá era como São Paulo para o Brasil. (A diferença é que, enquanto você caminha por São Paulo, você sempre tem que tomar muito cuidado. Em Montreal, você pode caminhar 24 horas, dia e noite, sem muita preocupação). Sinceramente, o estudo de lá eu recomendo para qualquer pessoa. A McGill é uma das melhores no Canadá. Pode ser considerada até uma das melhores no mundo. A experiência foi muito rica em todos os sentidos. No curso de Doutorado, às vezes, quando se saía para tomar um café com seus colegas, um deles às vezes era da Grécia, outro deles, da Índia, outro, da Itália, outro, da Inglaterra, e outro do Brasil. Então, note, quando você está com pessoas de outros países, não precisa nem ler livros para entender a cultura dos outros. Simplesmente falando com as pessoas, você entende a cultura, costumes e comportamento dos outros. Isso foi uma grande riqueza, de fato. Pude conhecer pessoas do Japão, da Coréia, dos Estados Unidos, de quase todo mundo...

(G.S.) Em que década foi a sua experiência?

(J.O.) Foi nos anos 1980.

Canadá: as universidades, as oportunidades de trabalho e a segurança (G.S.) Como você resumiria o Canadá?

(J.O.) Para os jovens, um país de oportunidades; para os profissionais, um país de crescimento e desenvolvimento; e para os velhos, um país de descanso, tranquilidade 
e garantia de qualidade de vida. Para a criança, o Canadá oferece todos os privilégios. As pessoas idosas, acima de sessenta e cinco anos, pagam, por ano, uma taxa de medicamento, pela qual recebem de graça quase todos os tipos de remédio. Agora, faz quatro meses, o Governo decidiu que, para qualquer pessoa com menos de vinte e cinco anos, os medicamentos são de graça, são por conta do Estado. Esta atenção vale também com relação ao estudo. No Canadá, por exemplo, quando eu estudava lá, nos anos 80, o custo anual de estudo era de quase mil dólares para um aluno, mas para o governo era de quase dez mil dólares. Vê-se o investimento sólido do governo na educação superior. Agora, você sabe muito bem, o Canadá é um país multicultural. As universidades são internacionalizadas, particularmente ainda, no mestrado e doutorado. Mas no começo dos anos 1980, aconteceu uma situação. Como nos Estados Unidos o estudo era (e é) caríssimo, o Canadá começou a sofrer uma invasão de estudantes estadunidenses. Inclusive mais do que de outros países, porque estão na fronteira. E o Canadá de fato não é um país discriminatório. O Canadá não discrimina ninguém. Se sua nota é oito, e a nota do canadense sete ponto nove, vão aceitar você e deixar o canadense fora. Então, isso acabou gerando um problema: essa invasão estadunidense começou a diminuir as chances e oportunidades para os canadenses. Então o Canadá reagiu. Aprovaram uma lei, acho que em 1982 ou 1983, determinando que o estrangeiro não residente tem que pagar integralmente o custo dos seus estudos universitários, enquanto que o canadense ou estrangeiro residente deve pagar apenas uma parcela. Vale explicar que no Canadá aquele que tem residência permanente tem todos os direitos. Sobre estes custos, variam de universidade para universidade. Depende de estado, porque a educação é responsabilidade estadual primeiro. Depende de cada universidade, porque as universidades têm grande autonomia, e do curso, também, porque alguns cursos são mais caros que outros. Por exemplo, o curso de medicina, em certas universidades, custa por ano de 20 a 60 mil dólares a um estrangeiro; mas, se você é canadense, paga apenas em torno de 10 a 15\% dos custos do seu estudo. Agora, se você não tem dinheiro, tudo bem. Aí o governo lhe dá dinheiro e você paga depois. Mas o dinheiro que o governo lhe dá não é só o dinheiro do estudo, porque o aluno não está lá só para estudar. Quer viver. Você pode trabalhar. O que eu gostei mais foi a flexibilidade do mercado de trabalho dos canadenses. Se você 
for aluno na universidade, você pode falar "Olha, eu necessito dinheiro, mas não posso trabalhar mensalmente, eu não posso trabalhar por semana, eu não posso trabalhar por dia, eu só posso trabalhar com o senhor aos sábados, por cinco horas", e o empregar responde, "senhor, eu aceito". Aí você vai a outro lugar e diz "ah, eu posso trabalhar nesse dia somente quatro horas". E aceitam. Então, tem essa flexibilidade. Mas tem aqueles casos em que você não tem condições de estudar e trabalhar ao mesmo tempo. Nesse caso, o governo canadense fala: "bom, eu posso pagar o seu estudo e estou disposto também; se você precisa, posso te emprestar dinheiro a ser devolvido no futuro com uma taxa de juros muito baixa para satisfazer outras necessidades". No momento, estão por aprovar uma lei nova, que assegura, a qualquer família com renda inferior a quarenta e cinco mil dólares anuais, que o estudo do filho que estiver na universidade ficará isento de qualquer custo. Se antes você pagava 10, 15 ou 20\%, agora, quando a renda familiar for de cerca de 4 mil dólares mensais, você paga zero por cento. Então note: O que você sente quando chega em um país em que você paga imposto e sente que tem retorno? Você paga, e quando paga, paga com prazer.

\section{(F.V.C.) Podes exemplificar?}

(J.O.) Eu, como canadense - e os meus filhos também são canadenses - tomei a decisão, dois anos atrás, de levá-los para estudar lá. No Canadá, tenho duas filhas na universidade, um filho que vai entrar na universidade, e duas filhas pequenas na escola. Aqui, quando minha filha estudava no Colégio São José, eu tinha que levar e trazer, e eu moro perto, aqui no centro. Mas quando minha filha chegou lá no Canadá (agora ela tem catorze anos), ela passou a estudar em uma escola mais distante de casa, a cerca de dois quilômetros. No entanto, agora ela me fala: "Pai, eu venho a pé, aqui é seguro". Ela me diz: "Pai, eu vou para a casa da minha amiga". Eu pergunto: "Onde fica a casa da sua amiga?" e “Quando vai?”. Ela me responde: “À noite, eu vou a pé e volto a pé”. Ou me responde: "Pai, eu vou de ônibus, eu vou para o centro da cidade de Toronto de ônibus". Então, você sente mais segurança lá. Com a segurança, o ser humano, a criança, sente mais desenvolvimento. Ela começa a procurar por si mesma a coisa que ela quer. A segurança dá mais opção, mais liberdade. Isso é uma coisa muito importante. Não vou 
dizer que lá não acontece nada em termos de violência. Tem problemas como em qualquer país. Mas comparando com Brasil e Pelotas, por exemplo, Pelotas chega a 62 homicídios até o momento em 2018, em uma população de quase 350000 (segundo IBGE), taxa que equivale aos países mais perigosos do mundo. Numa lista dos países mais perigosos, o Canadá figura em baixo. Dados sobre a criminalidade no Brasil e Canadá mostram que em 2015 houve 604 assassinatos em todo o Canadá; já no Brasil, no mesmo ano, foram quase 60 mil. Montreal, uma cidade de quase 2 milhões de habitantes, em 2016 registrou apenas 23 homicídios. Então, em termos de segurança, o Canadá é um país seguro, fator positivo que se soma à educação e ao atendimento médico.

\section{(G.S.) Além da segurança, o senhor considera importante outros aspectos?}

(J.O.) Além disso, há oportunidade de trabalho para os jovens, e para o jovem estudante. O jovem se sente realizado lá. Às vezes, de tantas opções de trabalho, o jovem se sente independente da sua família muito mais cedo. Aqui, o jovem fica mais tempo na casa da família, mas muitas vezes é pelo fator econômico. Por exemplo, no Canadá o salário mínimo é dezesseis dólares por hora. Perceba, não quero que todo jovem brasileiro vá para o Canadá (risos), mas o salário mínimo é dezesseis dólares por hora! O dólar canadense vale dois reais e sessenta centavos. Então, assim, 2,6 x 16 equivale a algo como quarenta reais por hora, aproximadamente. No mínimo, 46 reais por hora. Se você trabalhar lá oito horas por dia, chega a 80, quase 100 dólares canadenses, por dia. Claro que você, como aluno, às vezes vai trabalhar para sair de sua rotina. Até para te dar mais ânimo para estudar, você trabalha e estuda. Mas é nas férias que a maior parte dos estudantes gosta de trabalhar. Então eles têm essa situação, que contribui de fato para o crescimento, para o desenvolvimento, para o acesso às oportunidades.

(F.V.C.) E como estão avaliadas as universidades canadenses, do ponto de vista internacional?

(J.O.) As universidade canadenses são todas boas universidades. Entre as duzentas melhores universidades do mundo, vai encontrar muitas canadenses. É claro que outros países estão começando a despontar agora. A China está se sobressaindo muito, e mesmo a Rússia. 
(FCV) A McGill?

(J.O.) Sim. Agora, conforme dados de 2017, a McGill é a trigésima universidade em ranking mundial. Sabe quantas mil universidades você tem no mundo? Quantas mil você tem? É a única instituição canadense representada no Fórum de Líderes Universitários Globais do Fórum Econômico Mundial, que reúne os líderes de 26 das melhores universidades do mundo. McGill oferece mais de 300 cursos diferentes para mais de 40.000 alunos de 150 países diferentes.

\section{No Brasil, tem duas universidades que às vezes aparecem entre as duzentas, às vezes caem, às vezes sobem... a USP e a Unicamp.}

(F.V.C.) É um bom país para um brasileiro estudar?

(J.O.) Doutor Fábio, olha, é um lugar excepcional. Eu levei meus filhos para estudar lá, simplesmente para ter mais opções. Tem tanta escolha em termos de cursos e disciplinas optativas! Você estudando lá vai ter condições para focar no que você quer. Você quer estudar, por exemplo, Medicina. Bem, mas em que área? Você tem "n" disciplinas eletivas, para você focar em que você quiser.

(G.S.) E as bibliotecas para apoio ao estudante, como são?

(J.O.) Eu não disponho agora de uma estatística, mas a biblioteca da McGill, quando eu estudava lá, tinha em torno de oito milhões de livros. Eu não vou comentar nada, mas, um dia, quando perguntei para o pessoal daqui, quantos livros nós temos, disseram-me 190 mil livros. Eu não tenho dados sobre o grau de atualização desses livros. Agora, é bem diferente quando você cai em uma universidade assim, como a McGill, que dispõe de salas de leitura com todas as principais revistas de todos os campos da ciência, de quase todo mundo. Depois, temos as bibliotecas setoriais. Cada faculdade tem a sua biblioteca, e cada curso a sua. Cada curso tem o que se chama a Reading Room, uma sala de leitura especial para alunos. Ali tem livros, livros que não podem sair de lá, porque são livros raros, e aqueles exigidos nos cursos. 


\section{Canadá: multiculturalismo e imigração}

(G.S.) Na década de 1980, quando o senhor era estudante no Canadá, o país já era marcado pelo multiculturalismo, pela diversidade cultural

(J.O.) Vou dizer uma coisa para você: O Canadá é, de verdade, um país multicultural. O país tem a política imigratória. Por ano, aceita, no mínimo, de 240 a 300 mil pessoas. Todos os anos, então, sempre que você anda pelas cidades principais, toda vez que você vai ao downtown, no centro de Toronto, no centro de Montreal, é como você andar no centro de Nova Iorque. Difícil, talvez, achar "canadenses puros". Hoje, aqueles brancos são minoria nas grandes cidades. Atualmente, a maioria veio e são imigrantes. O Canadá sempre atrai, pois tem uma política de imigração bastante aberta. O Quebec tem uma política um pouco diferente. Segue a mesma política federal, mas tem certas particularidades. Cada embaixada canadense tem alguém que responde por assuntos específicos da província francesa do Quebec. Hoje se encontram muitos brasileiros no Canadá, graças à política de imigração.

\section{(G.S.) Quais as razões desta política de imigração?}

(J.O.) Como você sabe, os países de primeiro mundo têm taxa de natalidade mínima e quase zero ou mesmo negativa em certos países, como o Japão. Se fica negativa, é preciso aumentar a população. O Canadá está aumentando através da imigração. Os pais chegam de culturas diferentes. Mas o governo canadense exige, logo que você ingressa no país como imigrante, que seu filho esteja na escola já no segundo dia. No segundo dia! Eles oferecem todas as vantagens para o seu filho, para ser moldado segundo as normas de vida e cultura no país.

(G.S.) E essa política vem desde a década de 1980? Ou ela é mais antiga?

(J.O.) Antes, antes até! A primeira coisa a se observar: o Canadá para mim é um pais que pode ser considerado: "Second to none". Ou seja, você pode encontrar igual, mas melhor, não. Querem dizer o seguinte: Nós, Canadá, não estamos em primeiro, mas ninguém é melhor do que nós. 


\section{(G.S.) Em que por exemplo?}

(J.O.) Por exemplo... Na realidade, o Canadá é um país que tem tolerância. Se você veio dos Estados Unidos para o Canadá, ou do Canadá para os Estados Unidos, você sente a diferença cultural. Um povo muito educado, o canadense. Espero que os imigrantes vindos do terceiro mundo não prejudiquem esse conceito excepcional de tolerância, e de respeito. No Canadá, você tem todos os privilégios e liberdade quanto à tolerância cultural. Você pode falar qualquer língua que quiser, pode vestir o que você quiser. Mas todo mundo está enquadrado dentro da lei. E o Canadá, Quando fala que Canadá é um país multicultural, isto é levado a sério na política: Hoje em dia isto se reflete até na formação do governo.

(G.S.) Justamente...

(J.O.) Se você olhar o Ministro da Defesa (Harjit Sajjan), a segurança do país, e vais ver o ministério nas mãos de uma pessoa de origem indiana, usando o turbante.

(G.S.) Em uma comparação rápida, no Brasil, o Ministro da Defesa tem que ser brasileiro nato. Nem naturalizado pode ser.

(J.O.) Você encontra mais dois ministros lá de origem indiana. Uma ministra é do Afeganistão (Maryam Monsef, atual Minister of Status of Woman, anteriormente Minister of Democratic Institutions). O Canadá respeita muito as diferentes culturas e as religiões. Muito. Vivendo lá, ao andar por qualquer shopping, ninguém pode dizer "Por que você está vestindo assim?" ou "Por que você está falando assim?". Cada um fala sua língua, come sua comida. Você faz o que quer, enquanto você estiver dentro da lei. É isso que une todos os canadenses, a lei. $\mathrm{O}$ respeito pela lei.

\section{O Canadá e o Brasil: algumas comparações}

(F.V.C.) Omar, falando para um jovem brasileiro, qual seria a diferença entre o Canadá e o Brasil?

(J.O.) Então, se você perguntar para mim qual é a diferença... Vou dizer... Por que as pessoas às vezes não gostam do Canadá? Por que é frio? Frio, todo mundo fala 
do frio, certo? Mas os canadenses também aproveitam o frio, como aqui aproveitamos o verão. Eles têm os esportes de inverno. Aquele jogo de hóquei no gelo, originado no Canadá. Eu vivi quase sete anos e meio em Montreal e nunca consegui entrar em um jogo. Era tudo vendido muito antes. E vendido para quem? Cambistas. Aí você lá para assistir, e o que custa cem, duzentos dólares, está por oitocentos. Fica muito caro. Lá as pessoas são loucas por hóquei. E o esqui! Então tem jogos no inverno. Agora, são muito bem protegidos, muito preparados para o frio. Por exemplo, este ano passado fui para o Canadá, em dezembro. Aqui estava $32^{\circ} \mathrm{C}$. Quando cheguei lá e saí do aeroporto, estava $-20^{\circ} \mathrm{C}$. Ou seja, $57^{\circ} \mathrm{C}$ de diferença. Mas, de fato, eles são preparados para isso. Você entra dentro de casa e fica de T-shirt, de camiseta e calção, só.

(G.S.) E na comparação, que qualidades vocês veria em favor do Brasil com relação ao Canadá?

(J.O.) O que é um pouco diferente, por exemplo, entre Brasil e Canadá em termos de vida? Aqui no Brasil você tem mais calor humano. Lá as pessoas são mais frias. E o que deixa as pessoas mais frias ainda, que tem no Canadá e nos Estados Unidos, mas não tem no Brasil? É o que se chama de "guetos". Guetos querem dizer o que? Vêm pessoas do Paquistão e vivem na mesma área. Vêm pessoas da Índia e concentram em uma área. Pessoas da Itália, estão em outra área... No Canadá os guetos não são tão fortes como nos Estados Unidos, mas existem. Essa coisa de gueto, sabe por que acontece? Porque com a imigração, cada ano tem uma nova leva de imigrantes, e as pessoas novas, quando vêm chegando, procuram quem? Os de seu país. Mesma cultura, mesma língua. Agora isso no Brasil não existe, porque a imigração em massa parou nos anos 1960. Então qualquer pessoa que nasceu depois dos anos 1960 já é brasileiro. No Brasil, eu sei como você vai se comportar diante de uma situação, pois você tem a forma como o brasileiro vai se comportar, porque a cultura já foi moldada. O calor humano aqui é mais forte. As relações humanas são mais intensas do que lá. Isso é uma coisa diferente entre os dois países.

(F.V.C.) Além do calor humano, que outros aspectos positivos do Brasil tu ressaltarias?

(J.O.) Sim, claro, outra diferença é a qualidade dos alimentos. Por exemplo, você entra em qualquer supermercado no Canadá, e tem tudo o que você pode imaginar. Tudo. 
Mas a uva, chega do Chile, às vezes da Guatemala; a cebola, de El Salvador. Bem, tem tudo lá. Tudo que você pode imaginar. Mas... Mas aqui, quando você vai à feira, os produtos são mais frescos. A qualidade da carne que tem aqui não tem lá. Aqui o nosso animal vive no pasto, come pasto todo o ano. Lá o animal fica confinado por muito tempo, por causa do frio.

(F.V.C.) No Brasil a violência é uma das maiores preocupações. Como vês esta questão no Canadá?

(J.O.) Um país pacífico. Até quanto aos políticos, o Canadá sempre foi um país pacífico. Até agora é um povo pacífico. Não é violento. Não tem violência. Quando eventualmente acontece algo, está vinculado a grupos de crime organizado. Como não há pobreza, não há roubo, e não havendo roubo, não ocorrem homicídios. Primeira coisa então: Não precisa praticar roubo. Você não necessita. Porque se o seu pai não trabalha, ele conta com apoio dos Welfare Programs, da previdência social. O governo oferece o mínimo para viver. E você, sendo jovem, tem oportunidade de trabalho. Por que você vai roubar? Então, o crime por roubo praticamente não tem, é mínimo. E outra coisa, por que tem segurança? Porque você aplica a lei para todos. E, além disso, a escolha pela carreira policial lá é uma opção profissional. Não se é policial por falta de profissão ou de opção. Se você está nesta profissão é porque você é um policial por vocação, e ganha quase como um professor da universidade. O policial está lá porque ele quer ser policial, porque existe incentivo para ele, porque tem condições para ele viver bem, para a família dele viver bem, para oferecer uma vida digna para a família e filhos.

\section{Políticas de imigração e dilemas contemporâneos: o Canadá e a Europa}

(F.V.C.) Gostaria de retomar o tema da imigração. Colocaste que a política imigratória do Canadá é aberta, e assim a população vai sempre se renovando, e que esta é uma das grandes riquezas do país. Podes comentar um pouco sobre a racionalidade deste sistema?

(J.O.) De fato, a imigração sempre está inovando. O Canadá tem uma política de imigração diferente dos Estados Unidos. Qual é a política de imigração de Canadá? Se 
você quer ir para o Canadá, é assim: A primeira coisa, tem o sistema de pontos. Você vai ser entrevistado. Olham para a sua idade, porque a primeira coisa que eles querem saber é se você vai lá para viver por conta deles ou se você vai lá para dar primeiro e depois receber. Depois, olham para a qualificação, para a língua, se você viveu lá, se conhece a cultura deles ou não. Olham para todos esses fatores. Então eles chamam os candidatos à imigração conforme a pontuação. Assim chamam os melhores. Hoje em dia, a África e muitos países pobres reclamam dessa política. Por quê? Porque está tirando a nata destes países, particularmente da África. Eu vou dizer uma coisa para você. Só um exemplo: Por que os melhores jogadores de futebol estão na Europa? Porque recebem muito mais do que aqui. Então, porque, às vezes, os melhores médicos formados na África não estão lá na África? Porque fora eles recebem muito mais do que na África. A África não tem as mesmas condições de pagar! Aqui, o Brasil não tem condições de pagar para o Neymar o quanto ele quer, nem a Argentina pagar para Messi o quanto ele quer. E assim acontece com pessoas qualificadas. Isto se chama a política de headhunters, você vai buscar de fora as grandes cabeças.

(F.V.C.) Headhunters? É o que chamamos de migração de cérebros?

(J.O.) Sim, headhunters. Pega jovens, qualificados e talentosos, formados em países mais pobres, que vão trabalhar assim nos países que mais crescem. Entende? Crescem muito assim.

(G.S.) No cenário atual, o senhor acha que o Canadá manterá sua política imigracionista? Não estaria perto de um limite? Pergunto por que na Europa a questão imigratória, combinada à questão dos refugiados, tornou-se um problema de grandes proporções. Seria colocada como uma das causas principais do "Brexit”.

(J.O.) Observe, no Canadá tem em torno 37 milhões de habitantes. Por ano, aceitam 240 a 300 mil pessoas. 300 mil equivale a $1 \%$. O povo canadense está crescendo em torno de $0.2 \%$ ao ano, o que não é grande coisa. Por que eles precisam manter essa política migratória? Porque agora a expectativa de vida, ao se aproximar dos noventa anos, coloca uma questão: Quem vai sustentar a fatia da população que para de trabalhar a partir de 65 anos de idade? Quem? 
(F.V.C.) O jovem imigrante, que vem para trabalhar, e assim pagar imposto, contribuir para a previdência...

(J.O.) A Europa está mentindo. A Europa quer trazer todo esse mundo de gente da África e da Ásia. Eles querem trazer esses refugiados, mas eles querem pretexto. Pretexto: a guerra, os direitos humanos. Eles querem essas pessoas. Eles querem pessoas que tenham filhos, porque eles não querem ter filhos. Mas eles querem viver muito, mas quem vai sustentá-los? E aí, a Europa então, por bem ou por mal, quer esses imigrantes. Olha, na Europa tem acontecido coisas chocantes, de que a gente não gosta de falar. Eles têm muita discriminação e têm grupos de extrema-direita. Então tá, senhores. Digamos que eu vou tirar essas pessoas. Não querem que venha nenhum imigrante, nenhum refugiado. Então, eu gostaria de saber quantos têm filhos? Esse é o maior problema! Isso se chama problema estrutural. Um problema que tanto a Europa quanto o mundo avançado vai enfrentar. $\mathrm{Na}$ verdade, eles devem agradecer ao terceiro mundo... Devem agradecer à África, América Latina e Ásia. Devem agradecer a eles, porque ainda podem oferecer mão de obra suficiente para tentarem manter crescimento.

(G.S.) Por que está politica de imigração está funcionando bem no Canadá e não pode funcionar na Europa?

(J.O.) No Canadá as coisas acontecem dentro do previsto. Na Europa, eles não esperavam essa quantidade de imigrantes. E veja bem: esses imigrantes não são da Síria, que está sendo destruída por armamento americano e também europeu; não são líbios, que também foram destruídos por armamento europeu e americano; não são iraquianos, que também foram destruídos por armamentos europeus e americanos. Não, estão chegando de Paquistão, onde tem pobreza, da Índia, onde também tem pobreza. Vêm de Bangladesh, desses países pobres, de países pobres da África. Eu vi cenas na CNN, não sei se vocês viram também, de imigrantes que vão para a Europa e são vendidos e comprados como escravos em pleno século 21, por seiscentos, setecentos ou oitocentos dólares. A onda de imigração na Europa, por ter acontecido de uma forma tão grande, gerou reações, que às vezes são utilizadas para fins políticos. Assim foi na Inglaterra, com o Brexit. Usaram a imigração como pretexto para saírem da União Europeia. É apenas 
um pretexto para outras questões. Então, você utiliza as coisas para os seus fins políticos. Esse argumento da imigração saiu da Inglaterra: queremos uma raça mais pura, não queremos mais imigrantes. Bom, não quer, ok. Mas esses imigrantes que chegam agora, eles trabalham como lixeiro, profissão que você não quer como inglês. Eles trabalham em outra coisa em que você como inglês não quer trabalhar. Esse filho dele, amanhã, pode ser primeiro-ministro, grande profissional ou prefeito de uma grande capital, como Londres, onde o prefeito é de origem paquistanesa.

\section{Canadá e os desafios para uma política externa autônoma e pacifista}

(F.V.C.) E como avalias a politica externa canadense?

(J.O.) Na política externa, o Canadá sempre foi um país muito pacífico. As forças canadenses participaram nas missões da ONU (Organização das Nações Unidas), sempre. Até, talvez, uns quinze anos atrás, quando os "neocons", "novos Conservadores", ascenderam ao poder. Primeiro nos Estados Unidos, mas logo chegaram ao Canadá, de modo que a política externa canadense mudou radicalmente, começando a apoiar os Estados Unidos de forma cega. Antes não era assim. O Canadá sempre havia se destacado nas Missões de Paz enviadas pela ONU, conforme a índole pacífica do povo canadense. Politicamente, a chegada dos "novos conservadores" nos Estados Unidos influenciou a política externa do Canadá, ao menos até eles perderem recentemente as eleições para o atual primeiro-ministro Justin Trudeau, em 2015, pondo fim a uma década do governo conservador do primeiro-ministro Stephen Harper. É claro que o atual primeiro-ministro dificilmente vai se igualar ao pai dele, Pierre Trudeau, que foi um grande homem, um estadista excepcional. Mas é fato que ele tem carisma, juventude, presença e tem nome, tem Trudeau. A gente espera que, de fato, ele consiga avançar, particularmente nas relações relativas ao NAFTA (Tratado Norte-Americano de Livre Comércio). Agora está em questão a renegociação deste acordo.

(G.S.) E, na verdade, os Estados Unidos ficaram, agora, entre dois países (México e Canadá), de certa forma, isolados. Agora estamos vendo, também, a questão do aço, com relação ao Canadá. De certa forma, aparece, no próprio comércio, uma quebra entre a administração Trudeau e Trump. O que o senhor acha disso? 
(J.O.) Olha, é interessante que os liberais norte-americanos são mais liberais em termos de comércio. Mas esta figura que veio agora (o Trump), ele é muito mais protecionista que qualquer esquerda! Protecionista para quê? Para enriquecer às custas dos outros, porque ele tem o poder. Todo mundo sabe do poder econômico norte-americano. Entre 1944, depois da Segunda Guerra Mundial, e 1971, os Estados Unidos mandavam no mundo economicamente. A partir de 1971, teve o surgimento de potências econômicas como o Japão, a Alemanha, e como todo a Europa. Aí o poder econômico estadunidense diminuiu em termos relativos, mas mesmo assim nenhum país pode fazer muita coisa sem apoio norte-americano, ninguém. Eles têm o maior mercado do mundo. Então chegou esse cara para fazer política protecionista e está mostrando isso. Não vou entrar em uma aula de economia aqui, mas a política protecionista dos mercantilistas, desde 1350, como praticada seiscentos, setecentos anos atrás, pelas forças coloniais, pelo colonialismo, qual era a base dela? Qual a base do colonialismo antigo? Colonialismo é o que? Você vai ocupar outros países para servir como mercado para si, vender para eles, depois trazer matéria-prima deles. Agora, por outro lado, você protege, você vai restringir a entrada de produtos que seriam bons para o seu país. Foi isso que aconteceu. É isso que está fazendo hoje em dia o Trump, posso chamar isso de "Neo-Mercantilismo".

\section{(G.S.) E como tem se posicionado o Canadá no quadro atual?}

(J.O.) Então, o Canadá, hoje em dia, não está conseguindo marcar a autonomia da sua política externa. Por exemplo, a questão da morte do espião russo, que teria sido envenenado na Inglaterra. Ainda não sei se é mentira ou não. Não vou afirmar nada, mas acho que os ingleses mentiram. E aí, pela primeira vez a OTAN (Organização do Tratado do Atlântico Norte) quer mostrar unidade frente à Rússia. A Inglaterra expulsou não sei quantos diplomatas russos. Os Estados Unidos vão expulsar sessenta. E o Canadá também expulsou. Não sei exatamente quantos, quatro, ou dois, não sei quantos. Mas Canadá não deveria fazer isso, não deve...

(F.V.C.) Historicamente, não é a política do Canadá.

(J.O.) Não é a política do Canadá. Mas o Canadá agora não está conseguindo se descolar da política externa norte-americana. Sabe, tem certos países que não podem 
brigar. Por exemplo, Estados Unidos pode brigar com México, mas com o Canadá não, pois Canadá e Estados Unidos são quase um país integrado, quase uma mesma coisa. Até há pouco tempo, até 2001, canadenses e americanos entravam e saíam como se vai para o Uruguai. Agora mudou. Mudou porque indivíduos de muitos países começaram a utilizar tanto o passaporte canadense quanto o norte-americano para praticar atos em nome ou contra esses países. Isto tudo está relacionado ao 11 de Setembro. Não vou entrar nesse assunto, porque é um assunto sobre o qual também se precisa falar muito, é preciso se aprofundar, pois até agora tem muita gente que não acredita que o 11 de Setembro foi feito por Osama Bin Laden. Eu pessoalmente também tenho minhas dúvidas!! É uma pessoa que foi utilizada. E um arquivo que foi queimado. Agora, ninguém sabe a verdade (do mesmo modo, o mundo até o momento não tem certeza sobre quem matou JFK). Se você procura uma pessoa, você a pega, captura e a traz para a justiça. Por que você vai matá-lo? A mesma coisa fizeram com Saddam Hussein. Se o acham, tragam-no para a justiça. Não tem que enforcar. É o mesmo que fizeram com o Muammar al Gaddafi. São arquivos importantes para saber muita coisa na geopolítica internacional. O caso de Bin Laden, Saddam Hussein e Gaddafi, foi todos foram queima de arquivo.

(F.V.C.) Já que estamos falando de política externa, como vês a política externa brasileira com relação à Palestina, e como esta é vista pelos palestinos?

(J.O.) Se vai comparar politicamente a política externa dos Estados Unidos com a do Brasil, o nosso país sempre teve uma política externa coerente com relação à Palestina. Sempre, sempre, do começo até hoje. O Brasil sempre apoiou as resoluções da ONU em relação à questão da Palestina, e nesse assunto teve de fato uma política independente com relação aos Estados Unidos, na Assembleia Geral e no Conselho de Segurança. Talvez a única coisa que o Brasil não fez bem foi quando Oswaldo Aranha, na Presidência da Assembleia Geral, decretou feriado no dia em que os árabes tinham maioria, de modo a aguardar que os Estados Unidos e Inglaterra conseguissem ter mais votos para aprovar a sua proposta para o Estado de Israel em 1947. Mas o Brasil sempre teve política externa coerente e teve excelentes relações com o mundo árabe e o povo brasileiro é muito bem recebido no mundo árabe. Não vou falar isso sobre o estadunidense apesar que a 
cidadão Americano não deve ser condenado pela política externa Norte-americana, mas o brasileiro é muito bem-vindo, e o canadense também é muito bem-vindo na Palestina.

\section{Secretário-Geral da Confederação Palestina da América-Latina e Caribe}

(G.S.) E gostaríamos também que comentasse sobre sua trajetória na Secretaria Geral da Confederação Palestina da América-Latina e Caribe, a COPLAC.

(J.O.) Politicamente, fui, entre 1987 e 1993, Secretário-Geral da Confederação Palestina Latino Americana e do Caribe. Fui eleito em um Congresso no Peru. E de 1993 até o ano passado, atuei como Secretário-Geral adjunto. Essa organização é uma organização não governamental que engloba as federações de todos os países latinoamericanos. Em cada país podem existir diferentes associações, que formam uma federação nacional, e todas as federações da América Latina formam a Confederação. Trabalhei na Secretaria Geral para esta Confederação até o último congresso realizado em Manágua, no ano passado. Passamos tudo para a nova diretoria. A organização engloba todos latino-americanos, tanto palestinos como de origem palestina. As federações obedecem e se submetem às leis do país em que a comunidade se encontra. Em segundo lugar, defendemos a causa palestina, segundo as resoluções da ONU, e segundo o direito internacional, respeitando a política externa dos nossos países. É claro, se a política externa é errada, nós vamos contra. E é como brasileiros, como latino-americanos, e não como palestinos, que vamos contra. Exercer este cargo me deu, de fato, uma experiência muito rica. Deu-me a oportunidade para conhecer toda a América Latina. Não só os países, mas cidades nesses países, nesse continente. E também me deu a riqueza de conhecer muitos políticos da América Latina. Deu-me muita representatividade junto ao povo palestino, lá na Palestina e fora. Tivemos muitos encontros com as lideranças palestinas. Mais de uma vez com Yasser Arafat. Esses encontros proporcionaram uma experiência política rica, de conhecimento e convivência. Eu talvez não entrei na política exatamente por poder conhecer a política por dentro. Um dia foi ofertada a mim uma posição política. Quando me foi ofertado um cargo, conversei com um membro do grande escalão da Liderança Palestina, da OLP (Organização para a Libertação da Palestina). Alguém em quem eu sempre tive confiança, um cara de fato sábio e com rica experiência política e intelectual. 
Falei para ele assim: fulano, foi oferecido para mim tal lugar, tal posição. A resposta dele ficou como uma lição na minha vida. Quando eu perguntei “Qual é a sua opinião?”, ele me respondeu com uma pergunta muito pequena: "Olha, você tem condições para se sustentar sem trabalhar na política?". Ele sabia que eu era doutor, que poderia trabalhar na minha área. "Você tem condições?" Eu falei que sim. "Então, se você tem condições, vou dizer para você o seguinte, a política é um jogo sujo, para não dizer que não é limpo. Você quer entrar? Tem que usar uma bota até o joelho para não se sujar. Agora, se você tem como sustentar sua vida bem, com dignidade, sem entrar nisso aí, é melhor para ti ficar longe". Eu aceitei o conselho dele.

(G.S.) Poderias nos dizer quem lhe deu esse conselho?

(J.O.) Esse conselho foi de um senhor membro da liderança palestina. Um cara do núcleo interno. Daquele dia até hoje, para mim, vejo a política como um jogo. Eu não digo propriamente sujo, mas eu falo que não é limpo, para não falar a palavra sujeira. Mas o jogo não é limpo. Qualquer um que entrar na política, vai ser muito difícil sair limpo. E é por isso então que não me inseri muito na política. Preferi ficar na comunidade. Então, na Confederação Palestina se trabalha com a comunidade. É claro, este cargo dá muito acesso, porque como você representa uma comunidade de mais de meio milhão de pessoas, de setecentas ou oitocentas mil. Quando você vai falar com uma pessoa como Arafat, ele sabe que você representa oitocentas mil. Bom, aí isto significa que você tem um poder.

\section{A presença palestina no Canadá, no Brasil e na América Latina}

(F.V.C.) Comparativamente, como é a presença palestina no Canadá e na América Latina?

(J.O.) Na América Latina, temos uma comunidade de seiscentos ou setecentas mil pessoas de origem palestina. Estão em todos os campos de atuação, comércio, indústria, media, educação, política, em toda a atividade econômica. No Canadá, a comunidade é muito grande. Mas ocorre hoje algo parecido com a comunidade que veio da Índia ou do Paquistão. São caras jovens, qualificados, mas que não conseguem trabalho no país 
de origem. Eles vão para o Canadá porque dá trabalho para eles, dá segurança. Ontem eu conversava com a minha esposa, que está no Canadá agora. Ela tem uma conhecida casada com um médico que trabalha na Arábia Saudita, e ganham bem lá. Mas a amiga lhe disse que o seu esposo está pensando em sair de lá. Minha esposa pensou então que queriam voltar para a Jordânia ou Palestina. Não, o marido da amiga está pensando em mudar para o Canadá. Mas por que o Canadá? Bem, ela explicou que na Arábia Saudita vai acabar o contrato, e que eles não têm segurança alguma lá (no caso, segurança de estabilidade no emprego). Você pode ganhar vinte mil dólares por dia, mas seu boss pode chegar no segundo dia dispensando você do trabalho. Por que eles vão para o Canadá? Por que todo mundo quer ir para o Canadá? Porque todo mundo está sabendo que o Canadá dá ambiente, oportunidade de trabalho, segurança, e dá para os filhos deles educação e oportunidade de trabalho. Por isso, eu volto a dizer, o Canadá é "second to none”. Para mim alguém pode dizer que tem um país igual, mas melhor você não pode encontrar. Gosto muito...

\section{(F.V.C.) Omar, como vês a integração da comunidade palestina no Brasil?}

(J.O.) Aqui temos atualmente uma grande comunidade palestina. Mas, para o meu conhecimento, não existe um país no mundo que tem integração racial como esse país, apesar da existência de discriminação. Eu vou dizer para vocês uma coisa: nos Estados Unidos tem discriminação, na Europa tem discriminação. Aqui pode haver discriminação interna ainda, mas integração racial como esse país, eu nunca vi. Pode perguntar para mim: Por que? Porque eu posso notar isso. Se seu filho nasce aqui, ele sente que pertence a esse país, sente que pertence a essa cultura. A Dilma foi presidente do Brasil, certo? O pai dela era de onde? Bulgária, sim. Então, imagine: Segunda geração de imigrante, pai de fora do país, e ela tornou-se presidente do Brasil. E o Temer? O pai e a mãe dele são de onde? Do Líbano, não é? Os dois. Os irmãos dele nasceram lá. Ele nasceu aqui. E assim você nota o que estou argumentando. Eu, por exemplo, sou palestino, de nascimento, e brasileiro naturalizado. Mas aqui no meu trabalho não sinto discriminação alguma.

(G.S.) O senhor acha que o Brasil, guardadas as devidas proporções, tem semelhança com o Canadá, nessa questão de conviverem bem não importa a origem? 
(J.O.) Tem, tem semelhança.

(G.S.) Não que convivam todos bem o tempo todo, como o senhor mesmo disse. Ocorre algum tipo de xenofobia ou, enfim, de racismo, aqui em nosso país, mas mesmo assim se sente parte do país, não é?

(J.O) Você se sente parte do país. E vou te dizer, aqui no Brasil se sente ainda mais do que lá no Canadá. Aqui você sente mais porque aqui você não tem os guetos. Não tem, apesar de que você encontre a comunidade mais concentrada em um local ou outro. Mas você sente que faz parte desse país. Canadá é a mesma coisa. Lá o Ministro da Imigração do Canadá é imigrante da Somália, chama-se afro-canadense, como nós temos afro-brasileiro. Ele imigrou para o Canadá em 1993. E agora é ministro. Então quando você tem essa oportunidade, como você não vai sentir que você faz parte daquela nação? Como você não vai trabalhar para aquela nação? Quando o Brasil deu a oportunidade para imigrantes, todos eles sentiram que faziam parte deste país. Então todo mundo trabalha para o país. Agora, quando você começa a discriminar, eles começam então a trabalhar de uma outra forma. A melhor coisa é você dar para a pessoa segurança, oportunidade e respeito no campo de trabalho e na vida. Uma vez uma delegação palestina - quer dizer, uma delegação brasileira de origem palestina, porque todos nós aqui somos naturalizados ou brasileiros natos - falou para o Yasser Arafat: “O que você precisa de nós lá no Brasil?”. “Como podemos te apoiar, ajudar?" Sabe o que ele respondeu? "Se vocês querem me ajudar, para você ser bom palestino, você tem que ser primeiro um cidadão excelente no país onde você vive, para, depois, ser palestino". Porque, quando você é bom no país onde você mora, eles falam: "De onde veio esse cara?” Aí eles vão falar bem sobre você! E vão ter uma boa imagem do país de origem. Se você é mau onde você está, aí perguntam: “De onde veio esse cara?” ... “Da Palestina”. Então, primeira coisa, tem que ser honesto e servir ao país que deu a você a oportunidade, segurança, deu trabalho, deu a vida. Isso lhe dá mais sentido para fazer parte de uma nação e servir com toda dignidade. 


\section{Referências bibliográficas}

OMAR, Jabr H. D. Taxa de Juros: Comportamento, Determinação e Implicação para a Economia Brasileira. Revista de Economia Contemporânea, v. 12, p. 463-490, 2008.

OMAR, Jabr H. D. Globalização e Regionalização: Uma perspectiva Árabe. In: Relações entre o Brasil e o Mundo Árabe: Construção e Perspectivas. Brasília: Editora Fundação Alexandre de Gusmão, 2001a, p. 113-135.

OMAR, Jabr H. D. O papel do governo na economia. Indicadores Economicos, FEE Porto Alegre, v. 29, n.01, p. 211-235, 2001 b.

\section{Notas}

1 Os dois entrevistadores formularam e apresentaram perguntas.

2 Bolsista Produtividade do CNPq. Pesquisador Humboldtiano. Doutor em Antropologia Social (USP). Professor do Programa de Pós-Graduação em História e do Programa de Pós-Graduação em Memória Social e Patrimônio Cultural da UFPel. Brasil, Rio Grande do Sul, Pelotas. fabiovergara@uol.com.br.

${ }^{3}$ Formando em Direito pela Universidade Federal de Pelotas. Bolsista de Iniciação Científica FAPERGS. Interesse por Direito constitucional, Direitos Humanos, minorias, multiculturalismo. Brasil, Rio Grande do Sul, Pelotas. guilherme.stefan@gmail.com. 